This article was downloaded by: [Hansson, Heidi][UMEA Univesity]

On: 19 February 2009

Access details: Access Details: [subscription number 907835381]

Publisher Routledge

Informa Ltd Registered in England and Wales Registered Number: 1072954 Registered office: Mortimer House, 37-41 Mortimer Street, London W1T 3JH, UK

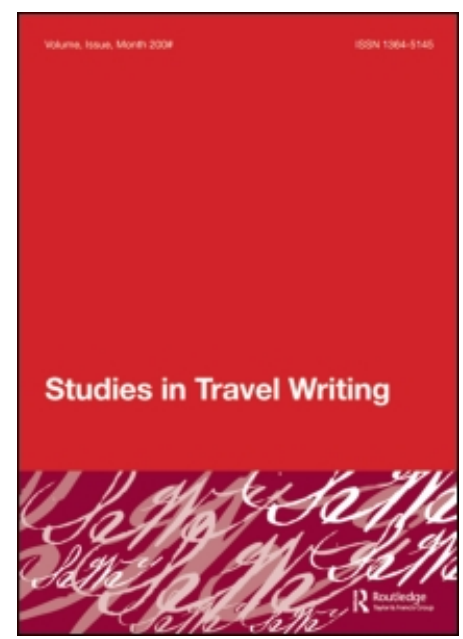

\title{
Studies in Travel Writing
}

Publication details, including instructions for authors and subscription information:

http://www.informaworld.com/smpp/title content=t902189980

\section{The gentleman's north: Lord Dufferin and the beginnings of Arctic tourism}

Heidi Hansson

Online Publication Date: 01 February 2009

To cite this Article Hansson, Heidi(2009)'The gentleman's north: Lord Dufferin and the beginnings of Arctic tourism',Studies in Travel Writing, 13:1,61 - 73

To link to this Article: DOI: $10.1080 / 13645140802611358$

URL: http://dx.doi.org/10.1080/13645140802611358

\section{PLEASE SCROLL DOWN FOR ARTICLE}

Full terms and conditions of use: http://www.informaworld.com/terms-and-conditions-of-access.pdf

This article may be used for research, teaching and private study purposes. Any substantial or systematic reproduction, re-distribution, re-selling, loan or sub-licensing, systematic supply or distribution in any form to anyone is expressly forbidden.

The publisher does not give any warranty express or implied or make any representation that the contents will be complete or accurate or up to date. The accuracy of any instructions, formulae and drug doses should be independently verified with primary sources. The publisher shall not be liable for any loss, actions, claims, proceedings, demand or costs or damages whatsoever or howsoever caused arising directly or indirectly in connection with or arising out of the use of this material. 


\title{
The gentleman's north: Lord Dufferin and the beginnings of Arctic tourism
}

\author{
Heidi Hansson*
}

\begin{abstract}
In his 1857 travelogue Letters from High Latitudes, Lord Dufferin positions himself as the first real tourist in the region of Iceland and Spitsbergen. The representation of these sites as tourist destinations involves a female gendering of place in comparison with the masculine image of the Arctic conveyed in, for instance, exploration narratives. The narrative is more an instance of self-writing than a report of observations, a privatising, subjective mode which again signals a move away from the pseudo-objective, masculine genres of scientific writing. Dufferin's aristocratic outlook is an important aspect of the self-presentation, emphasising the writer's refinement and good breeding. Nevertheless, one of Dufferin's central concerns is to convey the romance of the Arctic which builds on the image of man pitted against the forces of harsh and dangerous nature. The text can consequently be viewed as a site where conflicting gendered narrative traditions fuse or collide.
\end{abstract}

Keywords: Earl of Dufferin; Iceland; Spitsbergen; nineteenth-century travel writing; North; feminisation; gentrification

In nineteenth-century anglophone fiction, travel writing and exploration reports, the Arctic is usually depicted as the last frontier. It is an environment where nature is more powerful than human beings and where men might go to prove their strength and endurance. The cluster of associations surrounding the popular idea includes severe cold, distance from civilisation, dangerous conditions, barrenness and exposure to natural forces. Such images create 'a dramatic atmosphere for challenge and adventure', as Sherrill Grace notes in relation to understandings of northern Canada, and Peter Davidson suggests that even today, a 'voluntary northward journey implies a willingness to encounter the intractable elements of climate, topography and humanity'. ${ }^{1}$ Although there is a counterdiscourse based on the ancient notion of a hyperborean paradise, the view of a bleak, severe North is certainly more common. This cultural preconception frequently threatens to supersede experienced reality and is invoked also in accounts where writers or characters are never shown themselves to encounter the severity of a northern existence. The (generalised) North is consequently defined through climate and season to a much greater extent than the (generalised) South, so that winter is the reference point even in works set in the summer. Hence, when describing her arrival at Helsinki on a summer day at the end of the nineteenth century, the English travel writer Ethel Tweedie remarks: 'Somehow Helsingfors did not seem like a Northern capital, and it seemed hard to believe, in that brilliant sunshine, that for two or three months during every year the harbour is

*Email: heidi.hansson@engelska.umu.se 
solidly icebound'. ${ }^{2}$ To be truly Northern, Helsinki should have been covered in snow and ice, and the city's summer appearance is regarded as uncharacteristic.

Lord Dufferin's travelogue Letters from High Latitudes (1857), similarly, begins by invoking the notion of the far North as cold and dangerous, but the overall idea of the region finally produced in the text is one of beauty, delight and even comfort. The literary style of the work and the upper-class outlook of the writer produce a more aristocratic and more feminine image of the northern journey than in many other works, and in Dufferin's travel book, the northern tour is primarily presented as a gentlemanly pursuit. The semiprivate letter-format, the personal tone, the sophisticated style, the humorous distance to the author's self and the preponderance of topics associated with women's tastes announce an adherence to what is often understood as a feminine paradigm rather than to the conventional masculine image of the Arctic. But since the cliché of the stern, demanding North is brought in from the start and frequently reinforced in the illustrations, the work becomes a dialogue between two versions of the region. Dufferin's account can therefore be viewed as a site where a predominantly masculine paradigm continuously collides with a principally feminine model.

Frederick William Hamilton Temple Blackwood, Earl of Dufferin (1826-1902) belonged to the Irish nobility and became a distinguished diplomat for Victorian Britain. He acted as Governor-General of Canada 1872-1878, functioned as Ambassador to Russia, the Ottoman Empire and France and was the Viceroy of India 1884-8. In 1888 he was created the first Marquis of Dufferin and Ava. He came from a literary family as the great-great-grandson of the playwright Richard Brinsley Sheridan, and his mother, Lady Helen Dufferin, published poetry, plays and the travelogue Lispings from Low Latitudes, or Extracts from the Journal of the Hon. Impulsia Gushington (1863), describing a journey on the Nile and punning on the title of her son's famous book about the North. It was praised as 'one of the wittiest and merriest of jeux d'esprit' and subverts the genre of travel literature by focusing on the foibles of travellers rather than on sights and experiences. ${ }^{3}$ According to his biographer Sir Alfred Lyall, Dufferin derived most of his personal characteristics from his mother's side and was a representative member of a family who had preserved 'the vivacious qualities of a race endowed by nature with striking attractiveness of person and manner, with lively wits and intelligence, with highspirited, uncalculating generosity'. ${ }^{4}$ These character traits are observable in Dufferin's travelogue, Lyall suggests, and contribute to its charm. ${ }^{5}$

Letters from High Latitudes was first published in 1857 and came out in new editions throughout the century, the 11th edition published in the Everyman series in 1903. The book was reviewed together with Sabine Baring-Gould's Iceland: Its Scenes and Sagas (1863) despite the six-year difference in publication dates, because, according to the reviewer James Anderson Scott, 'Lord Dufferin's work did not pass away with the ephemera of its season, but is still read with avidity'. ${ }^{6}$ The work's high cultural status meant that later northern travellers frequently cite it as an inspiration, as in the first few words of Sir William Martin Conway's The First Crossing of Spitsbergen (1897):

It was in Lord Dufferin's 'Letters from High Latitudes' that Spitsbergen first emerged, for me, from the fogs and darkness of Arctic mystery, as a land of mountains and glaciers, of splintered peaks and icy bays, a place worth seeing and even worth going to see. ${ }^{7}$

The immense popularity the book enjoyed throughout the second half of the nineteenth century has ensured that it has remained in circulation, with a reprint appearing as late as 2006. Letters from High Latitudes has also inspired at least one sequel, Tim Moore's Frost on My Moustache: The Arctic Exploits of a Lord and a Loafer (1999). ${ }^{8}$ 
Dufferin's travelogue describes a journey to Iceland, Jan Mayen and Spitsbergen, which means that the text can be related to the normally masculine-gendered tradition of exploration reports or stories of whaling such as Moby Dick (1851). An emphasis on traditionally masculine virtues is common in accounts of northern travels, and the courageous nature of the northern traveller is even considered a selling point, as is evident in the advertisements for Dufferin's countryman the Hon. Arthur Dillon's two-volume work $A$ Winter in Iceland and Lapland (1840):

Iceland and Lapland are all but untrodden regions. Mr. Dillon, inured to the hardships of a northern winter, was induced by the interest he took in these nations to attempt the hazardous expedition of visiting them in their remote and unfrequented homesteads; and these volumes, full of information, historical and descriptive, are the result of a journey not less creditable to his literary character than his courage. ${ }^{9}$

Iceland became increasingly popular as a tourist destination in the nineteenth century, primarily as a result of the widespread interest in Old Norse mythology and the Icelandic sagas, but as Andrew Wawn makes clear, the country was still constructed as 'a worthy challenge'. ${ }^{10}$ Among others, Wawn refers to James Anderson Scott who wrote in the Dublin University Magazine in 1863 that 'Iceland is not an inviting region to the dandy order of tourists; but the excitements of its scenery and life are novel, and possess strong attractions for the person imbued with the true spirit of travel'. ${ }^{11}$ Although the US travel writer Bayard Taylor did not visit Iceland until 1874, he travelled in Sweden and Norway in 1856-7 - at the same time as Dufferin's journey took place - and to a certain extent his Northern Travel. Summer and Winter Pictures of Sweden, Lapland, and Norway (1858) can be seen as typical of what could be termed male-coded travel writing about the North at the time. At least in the descriptions of the winter journey through northern Sweden, Taylor shows how the North provides him with an opportunity to test his physical prowess and prove his masculinity. ${ }^{12}$ The northern region is shown as harsh and demanding in his text, and is gendered masculine in relation to the fertile South. Egypt, in Taylor's description is 'a world of glorious vitality', whereas in Lapland, '[1]ife existed only on sufferance'. ${ }^{13}$ Measuring himself against the tough conditions of a northern winter Taylor manages to both emphasise his own manliness and present the region in masculine terms.

Juxtaposed with Taylor's text, Dufferin's description can instead be regarded as participating in a process that softens the North, despite James Anderson Scott's insistence that Dufferin should not be included in the 'dandy order of tourists'. According to Lyall, Letters from High Latitudes belongs to a tradition he calls 'the amusing narrative of genuine travel', begun by Alexander William Kinglake in Eothen, or Traces of Travel, etc., Brought Home from the East (1844) and continued by Robert Curzon in Visits to Monasteries in the Levant (1849). The characteristics of this subgenre, as Lyall sees it, are

$[\mathrm{K}]$ een yet good-natured insight into strange and simple morals, manners, and institutions, the habit of taking mishaps and hardships with humorous philosophy, of dealing sympathetically with men of the rough unvarnished world, and of giving a comical turn to petty incidents or vexations - combined with a strong sense of the picturesque, a taste for intelligent research, and an earnest interest in primitive folk - these are the qualities which must be united for success in finding adventures and writing about them. ${ }^{14}$

Lyall's definition of 'adventures' is consequently a clear departure from the conventional idea of Arctic exploits and the phrase 'finding adventures and writing about them' indicates that fictionalisation is - even should be - a feature of a text belonging to this subset of travel writing. The semi-fictional approach, the self-mocking tone and a clear distancing from the heroic paradigm characterises also Tim Moore's sequel Frost on My 
Moustache, suggesting that Moore attempts to emulate Dufferin's journey not only geographically but also in terms of its literary representation.

Like Kinglake and Curzon, Dufferin is a story-teller, not primarily a fact purveyor. He positions himself not as an adventurer of Taylor's ilk, but as the first real tourist in the region and the representation of Iceland and Spitsbergen as tourist destinations involves a female gendering of place compared to the masculine image of the Arctic conveyed in exploration narratives. ${ }^{15}$ This distancing from the more heroic images of Arctic travel becomes even greater since Dufferin's journey took place at a time when the fate of Sir John Franklin and the members of his expedition to map out the North-West Passage was frequently speculated upon. The expedition had been last sighted by Europeans in 1845, and throughout the 1850s a great number of well-publicised search expeditions attempted to discover what had happened to the party. ${ }^{16}$ The public image of the Arctic was consequently as a dangerous zone where visitors risked their lives. The idea was circulated in the newspapers, through the activities of learned institutions like The Royal Geographical Society and in travel books like Bayard Taylor's Northern Travel. ${ }^{17}$ Dufferin's text, however, continually deflates the notion of the North as a testing-ground for heroes.

Both the exploration discourse and the tourist discourse contain details about food, accommodation and the attitude of locals, but the difference is that in exploration reports, such information is frequently presented as part of what makes the venture challenging while in tourist narratives it is included in reviews of the comfort or discomfort of various lodgings along the way. The tourist discourse primarily draws attention to leisurely pursuits, not hardships. Dufferin brought his own comfort since he journeyed north onboard his own schooner the Foam, and his narrative clearly shows that it is possible to travel to the region without having to relinquish any gentle habits. The ship contains a

snug, well-lighted little cabin, with the firelight dancing on the white rosebud chintz, the wellfurnished book-shelves, and all the innumerable knick-knacks that decorate its walls, little Edith's portrait looking so serene, everything about you as bright and fresh as a lady's boudoir in May Fair. ${ }^{18}$

As Dufferin points out, it is a remarkably feminine environment, furnished and decorated like a lady's room rather than a ship's cabin. A similar comfort characterises the travelling party's trip overland to the Geysers in Iceland, with Dufferin's man-servant Wilson setting up the tent and organising the camp:

Having carpeted the floor with oil-skin rugs, and arranged our three beds with their clean crisp sheets, blankets and coverlets complete, at the back, he proceeded to lay out the dinner table at the tent door, with as much decorum as if we were expecting the Archbishop of Canterbury. (59)

Dufferin also sends his cook to the campsite in advance so that dinner may be prepared and everything be in order when the travellers arrive at their various destinations (69). $\mathrm{He}$ is awakened in the mornings by Wilson who brings hot water for washing and shaving (184). Through descriptions such as these, Dufferin distances himself from the paradigm of heroic exploration and by showing the journey as an aristocratic pastime he writes himself into a female rather than a male tradition of travel writing.

Dufferin's account draws attention to the writer's refinement and good breeding and his difference from, for instance, the rough sailors populating the whaling stories or the dedicated scientists willing to endure difficult conditions in their pursuit of new discoveries. The steward Wilson is really the only member of the party who is shown to 
find the journey arduous, but since he is described primarily in comic terms, his negativity mainly functions as a contrast to Dufferin's positive outlook. According to Lyall

[t]he figure of Wilson the steward, dismal and atrabilious, who saluted his master of a morning with the gloomiest news of the weather and the ice, in the voice of one foredoomed to perish, stands out as a foil to the skipper's cheerfulness. ${ }^{19}$

A result of the humorous accounts of Wilson's reactions is that the ice and the cold never really come to represent the dangers of the Arctic in the text. Instead, the difficult conditions become minor obstacles that the more well-bred people onboard are able to laugh away, as they laugh at Wilson together with the reader. The ideal outlook, embodied in Dufferin, is the ability to 'experience adversity with detached jocularity', as Tim Moore observes. $^{20}$

Jón Stefánsson's Preface to the 1903 edition of Letters from High Latitudes highlights the writer's aristocratic character from the start:

Rarely, if ever, has a more interesting visitor set foot on the historic soil of Iceland than this Irish nobleman, thirty years old, Irish of the Irish, the beau ideal of the aristocracy, full of irresistible charm and fascination. ${ }^{21}$

The implication is that Iceland is interesting because Dufferin chose to visit, not the reverse. The introductory epigraph from Francis Bacon's essay 'Of Travel' foregrounds the importance of the writer in another way, by indicating that the narrative is more an instance of self-writing than a report of observations:

It is a strange thing, that in sea voyages, where there is nothing to be seen, but sky and sea, men should make Diaries; but in land-travel, wherein so much is to be observed, for the most part, they omit it; as if chance were fitter to be registered than observation. (n.p.)

Bacon's purpose is to encourage diary-writing among his travelling contemporaries and the essay calls for precisely the kind of factual information that Dufferin's narrative frequently omits. ${ }^{22}$ Taken out of context and used as an epigraph, however, the passage rather functions to emphasise the personal, introspective aspects of diary-writing. The privatising, subjective mode of Letters from High Latitudes exemplifies a move away from the pseudo-objective, masculine genres of scientific writing or the list of observations Bacon had in mind, and when Dufferin attempts to provide more technical explanations he is anxious to announce his amateur approach. Thus in a footnote to his description of Thingvalla [Pingvellir] in Iceland, he writes: 'I feel it is very presumptuous in me to hazard a conjecture on a subject with which my want of geological knowledge renders me quite incompetent to deal' (52, note 2). The declaration belongs to the same genre as the avowals of modesty introducing so many women's works from the Early Modern period onwards, although in Dufferin's case it does not suggest anxiety of authorship so much as the announcement of a non-specialist outlook. ${ }^{23}$ It is obvious, however, that although the selfdeprecating footnote and the personal style are meant to draw attention to Dufferin's amateur status, they are certainly not intended to suggest insufficient knowledge. The description of Thingvalla [Pingvellir] is accompanied with an illustration of the geological features of the place, showing Dufferin's solid education (55). But the drawing also includes a stick figure with the caption '[a]stonished traveller', again underscoring his selfdistance. Together, the text and the illustration manage to indicate both that Dufferin is very knowledgeable and that he has no real need to display his expertise.

The lightly carried learning is crucial also for establishing Dufferin as a true gentleman. In the Restoration period and the eighteenth century, any display of erudition ran the risk of being dismissed as pedantry, and the fear of being seen as a pedant could even make 
members of the gentility shy away from intellectual pursuits. ${ }^{24}$ Although certain forms of learning, such as antiquarianism, history and natural history were recommended for gentle society, it remained important not to be too serious about their study. ${ }^{25}$ Gentlemen engaged in scholarly activities should assume 'an air of effortlessness, casualness, and aristocratic nonchalance which differentiated them from pedants and professional scholars'. ${ }^{26}$ This view of science as a gentlemanly accomplishment persisted for much of the nineteenth century, resulting in an unusually important position for the amateur or dilettante in British scientific culture. ${ }^{27}$ By showing himself as casually well-informed, Dufferin consequently reinforces the image of himself as a true gentleman.

Apart from presenting himself as an upper-class gentleman, Dufferin seems to take it for granted that his audience will be on his social level. He expects, for example, that the readers will be able to understand a speech composed of quotations in Latin, recognise words in Classical Greek and read a long article from a French newspaper in the original language, and that a reference to Virgil's Eclogues will be sufficient to give a sense of his and his crew's pastoral life in the north of Norway $(41-42 ; 40 ; 137-44 ; 145)$. This is of course not unique to Dufferin, and in travel writing in general, literary and artistic allusions often function as a means to familiarise the foreign, as well as to establish a relationship between writer and audience as members of a cultured elite. In nineteenthcentury bourgeois culture, travel books were sometimes justified on the grounds that they were instructive. Compared with the frivolous novel, travelogues could be recommended as worthwhile reading. Dufferin's main purpose is to amuse, however, not to teach, and he addresses readers who do not primarily seek instruction but entertainment.

The 'letters' that organise the narrative are ostensibly addressed to Dufferin's mother, which underscores the upper-class context as well as genders the work feminine to a certain extent. Discourses generally associated with women in the nineteenth century were the confessional, the private letter, the informal conversation and the familial anecdote - all of them personal rather than public modes of expression. ${ }^{28}$ As Shirley Foster sees it, women may choose the journal or letter form to emphasise their "private and domestic orientation'. ${ }^{29}$ By shaping his narrative as a set of letters Dufferin thus adopts what by the mid-nineteenth century was often regarded as a feminine mode of writing. The personal style is typical of touristic travel writing as such, however, regardless of whether the writer is a man or a woman. If Madame de Sevigné's letters can be regarded as models where letter-writing is concerned, Laurence Sterne can be seen as the pioneer for a more personal approach to travel writing through his influential novel A Sentimental Journey (1768).

A more important factor than style when it comes to the gendering of the text is the role of the addressee. Discussing the composite and constructed nature of any travel narrative, James Duncan and Derek Gregory mention that when Gustave Flaubert travelled up the Nile in 1849-50 he kept a journal 'which he used not only as an aidemémoire but also as the basis for letters to his mother and to his male friends at home in France (so that there are often different constructions of the same event and place)'. ${ }^{30}$ Implicit in Duncan and Gregory's comment is the idea that male and female recipients may receive different accounts. In Letters from High Latitudes, Lady Dufferin is constantly present as the mother worrying about the whereabouts of her son $(17,192,202)$, the woman who should not be wearied with tedious details (169) or as the symbol of home that makes Dufferin homesick (240). She is directly addressed on a number of occasions and it seems clear that Dufferin has selected his details with a view to what might be of interest to his mother - or possibly to his general idea of the taste of a woman reader. It is plainly 
indicated, for instance, that he does not expect women (as represented by Lady Dufferin) to be familiar with the workings of a sextant:

Now, out of tenderness for your feminine ignorance, I must state that, in order to make an observation, it is necessary to get a sight of the sun at a particular moment of the day: this moment is noon. (203)

Instead of providing technical information, Dufferin concentrates on what Foster identifies as common feminine topics: 'appearance, costume and manners of women; details of domestic life such as household management and culinary habits; behaviour towards children; marriage customs and female status'. ${ }^{31}$ Although Foster might come close to essentialist ideas of femininity it is clearly a list of topics that would have appealed to the nineteenth-century separate spheres ideology of gender. Apparently adhering to such an understanding of woman-oriented content, Dufferin focuses on the pretty appearances of the houses when describing Reykjavík:

the rows of flower-pots that peep out of the windows, between curtains of white muslin, at once convince you that, notwithstanding their unpretending appearance, within each dwelling reign the elegance and comfort of a woman-tended home. (25)

At the Geysers he describes how his cook turned one of the hot springs into a camp-kettle and dug a sort of oven in the hot clay (75) and a colony of eider ducks is placed in a female as well as an upper-class frame of reference by his explanation that

the nests are gathered, cleaned, and stuffed into pillow-cases, for pretty ladies in Europe to lay their soft, warm cheeks upon, and sleep the sleep of the innocent; while long-legged, broadshouldered Englishmen protrude from between them at German inns, like the ham from a sandwich, and cannot sleep, however innocent. (28-9)

After going to church, Dufferin provides a detailed description of the Icelandic women's clothes clearly addressed to his mother, giving information about the general style as well as the ornaments on the dresses (29). He also comments on the marriage and divorce laws, a topic that seems to have been of great interest for British travel writers in the period leading up to the widely debated Divorce and Matrimonial Causes Act of 1857. ${ }^{32}$ For Dufferin, the issue would probably have been of even more profound interest since his mother's sister was Mrs. Caroline Norton whose pamphlets criticising laws that discriminated against women were directly instrumental in the final passing of the Act.

Dufferin's account of Icelandic life also includes information on women's occupations such as carding and spinning wool, the food of an ordinary family and habits of breastfeeding (89). A particularly clear subversion of the male-oriented narrative is his description of a ball given by the French Prince Napoléon, who also visited Iceland in the summer of 1856. The ball took place on board the Prince's frigate the Reine Hortense which was transformed from a warship to a ballroom:

Every wall was gay with flags; the frigate's frowning armament all hid or turned to ladies' uses: 82-pounders became sofas; boarding-pikes, balustrades; pistols, candlesticks; the brass carronades set on end, pillar-wise, their brawling mouths stopped with nosegays; while portraits of the Emperor and empress, busts, colours draped with Parisian cunning, gave to the scene an appearance of festivity that looked quite fairy-like in so sombre a region. (98)

Susan Bassnett opposes Shirley Foster's view that certain literary manners are more feminine than others and claims that there are no obvious stylistic differences between men's and women's travel writing. The differences can instead be found in the selection and presentation of material and - vitally in the case of Dufferin's text - 'in the 
relationship between the traveller and the putative reader' ${ }^{33}$ It seems clear that Dufferin's material has to a great extent been chosen to correspond with what he regards to be of female interest. This means that not only actual experiences and observations, but also metaphors and similes can be related to his understanding of the female sphere. Accordingly, he describes the floating ice around the schooner as a diamond necklace (120) and a large rock as a dining table (204). The narrative itself, on the other hand, is characterised by refinement, elegance and at times, a certain self-mockery, which says nothing about any particular gendering of the text. The nineteenth-century separate spheres ideology that prescribed certain rules for women and others for men was primarily a middle-class phenomenon, and several of Dufferin's descriptions may just as easily be incorporated in what might be called an aristocratic paradigm as in a womancoded model.

Nevertheless, the rationale for the narrative is the romance of the Arctic which builds on the image of man pitted against the forces of harsh and dangerous nature. Dufferin is thus predisposed to placing his northern experiences in an interpretative paradigm based on the idea of the far North as frozen and desolate. As James Duncan and Derek Gregory see it, 'the travel archive is fractured' partly because written accounts are dealt with by literary scholars and historians and pictures and photographs are assigned to art historians. To achieve a fuller sense of how geographical regions have been understood and represented, it is necessary to read different media together. ${ }^{34}$ They also acknowledge, however, that each medium has its own set of conventions. Most of the illustrations in Letters from High Latitudes conform to a view of the North as a perilous environment, and an important reason for this may be that rough seas, steep mountain walls and icebergs are more familiar pictorial subjects.

Together with the contradictions in the text, the interaction between text and illustrations means that the work can be viewed as a site where conflicting gendered narrative traditions fuse or collide. The cliché of an icy, dangerous environment is constantly present as a background, in dialogue with the experiences recounted in the text. The poem to the figurehead of the Foam that introduces the narrative thus paints a picture of a harsh, forbidding northern region. The wind carries the ship to

eternal winter's dread domain,

Where suns of June but frozen light distil (1)

The ice that gathers around the schooner is likened to a flock of wolves, further emphasising the sense of danger:

The ominous shapes of drifting ice, that pack

The desolate channels of the polar flood,

Clustered like wolves around our Northward track (2)

Words denoting desolation, barrenness and difficult conditions contribute further to characterising the Nordic North as an area of snow and ice: 'stern [...] icebergs', 'Arctic gloom', 'bleak and barren ocean tracts' (3). Yet, when Dufferin finally encounters the ice-floes his description is couched in considerably more positive terms:

In quaintness of form, and in brilliancy of colours, these wonderful masses surpassed everything I had imagined; and we found endless amusement in watching their fantastic procession. (120)

Instead of elaborating on the threatening aspects of the North suggested in the introductory poem, he notes that the sea is as filled with ice as 'a lady's boudoir is with furniture' (130). Nevertheless, the association between demanding cold and northerliness is 
extremely strong, and snow and cold return as a frame of reference in the text even when Dufferin's experiences clearly indicate the opposite:

The snow, however, beyond, serving as an ornamental fringe to the distance, plays but a very poor part at this season of the year in Iceland. While I write, the thermometer is above $70^{\circ}$. Last night we remained playing at chess on deck till bedtime, without thinking of calling for coats, and my people live in their shirt sleeves, and - astonishment at the climate. (24)

'According to the model of cultural critique founded on the idea of projection', write Felix Driver and Luciana Martins, 'Europeans often saw what they wanted to see when they travelled into the tropics'. ${ }^{35}$ The same is obviously true about northern regions. As the Canadian geographer Louis-Edmond Hamelin continually points out, the North has to be understood on a conceptual as well as a geographical level, and Dufferin's account shows that the degree of wintriness is a fundamental aspect of this conceptualisation - regardless of whether the winter is actually present or only imagined. ${ }^{36}$

It seems, then, that Dufferin adheres to the adventure paradigm more or less because it is expected in an account of the far North, but that his actual experiences only rarely correspond to the pattern. He certainly does experience biting cold occasionally and remarks that the northern climate 'would not have been unworthy of Dante's Inferno' and that Spitsbergen is a place of 'eternal ice', but the sections of his text describing really difficult conditions are fewer and shorter than the ones focusing on beauty or history $(101,180)$. After the troublesome passage from northern Norway to Spitsbergen he simply comments, with address to his mother:

But why should I weary you with the detail of our various manœuvres during the ensuing days? They were too tedious and disheartening at the time for me to look back upon them with any pleasure. (169)

Pleasure and enjoyment guide Dufferin's narrative, both because of a concern for the reader and for his own sake. A text emphasising the dangers of the North would probably have included a full description of the problematic journey through the ice instead. Thus, the illustrations produce an overall vision of the North different from that produced in (or by) the text since they focus on points that remain unsaid or understated in the narrative, such as the littleness of man in relation to northern nature, or the quite difficult conditions of sailing through the ice-laden sea.

As a genre, travel writing lies between fiction, self-writing and scientific reports, and in Lord Dufferin's case, the element of fiction is quite prominent. The book is supplied with a list of Dramatis Personæ which suggests that the travellers are characters in a play (n.p.), and on a couple of occasions Dufferin comments on Norwegian history in the form of long poems instead of offering a more neutral description (211-13; 235-39). He retells Norse sagas and myths to call up 'heroic phantom[s] from Norway's noble past', but his stories usually concentrate on the love interest as much as on heroic deeds, questioning the widespread Victorian idea of the ancient North as a place only for tough Vikings (213). At the same time, however, he subscribes to the view that the English nobility can trace its origins back to the Norse Vikings. ${ }^{37}$ His selection of stories and story elements contribute to both a feminisation and a gentrification of the Nordic North.

The effect of Dufferin's work can to a great extent be attributed to the textual presence of Lady Dufferin as the recipient, but the self-presentation of the writer is obviously of at least equal importance. Though it is hardly the choice of a physically weak person to embark on a sea journey to Iceland and Spitsbergen, Dufferin never attempts to show himself as a sportsman or an adventurer in any sense. On the contrary, he frequently adopts a tone of self-mockery when writing about his exploits. After leaving Iceland, 
Dufferin's schooner the Foam accompanied Prince Napoléon's frigate the Reine Hortense on the way to the island Jan Mayen, but the French ship encountered some problems and had to turn back. When describing how he was called to the deck to receive a message to this effect from the French frigate, Dufferin compares himself to a picture from a fairy tale:

I was so irresistibly struck with my own resemblance to a coloured print I remember in youthful days, representing that celebrated character 'Puss in Boots', with a purple robe of honour streaming far behind him on the wind, to express the velocity of his magical progress, that I laughed aloud while I shivered in the blast. (122)

Instead of emphasising how the little schooner was left alone to brave the Arctic waters while the larger French ship went to a safe harbour, Dufferin laughs about looking like a fairy tale character. He continues to puncture any sense of adventure or hardship by relating how he sent a few messages over to the French using a milk can (123). Such domesticating devices remove the text even further from the heroic paradigm of other Arctic tales. His description of Spitsbergen scenery is quoted from William Scoresby, $A n$ Account of the Arctic Regions (1820), and he faithfully relates Scoresby's comments about the danger, the hazardous descent and the sometimes painful undertaking (190) of climbing the island's mountains. When he imparts his own experiences, however, the sense of peril is absent: he and his companions obtained their sights 'from a lower elevation, and certainly without the risk' described by Scoresby (190). 'Mountain climbing has never been a hobby of mine', Dufferin writes, though he has been pronounced 'to be a very tolerable waltzer' (228). Dancing held a particular position in the education of a gentleman since it was regarded as a way of learning to move with grace, and Dufferin again shows himself to be a product of the educational ideals of his social class. ${ }^{38}$ Style, elegance and social graces are foregrounded in the narrative, showing that Dufferin certainly does not live up to any ideal of a manly Arctic explorer but at the same time, robbing the northern region of some of its challenge and mystique. If the treacherous waters around Spitsbergen can be presented as an appropriate setting for a gentleman tourist, the area becomes less suitable as an environment for heroes. In this respect, the work can be seen as a response to a nineteenth-century conflict between imperial masculinity or Charles Kingsley's and Thomas Hughes's muscular Christianity and the gentlemanly sophistication surviving from the ideals of the Regency period. As Anne Windholz comments in connection with gentleman emigrants to America, there was a fear that a failure of such ventures 'might signify the degeneration of British masculinity and imperial prowess' that competed with 'an anxiety that the emigrant who succeeds and validates his manhood might in the process forfeit his status as gentleman'. ${ }^{39}$ At one level, Dufferin's text thus functions as a manual for gentlemanly behaviour.

Nevertheless, there is no sense that Dufferin's masculinity should be compromised by this downplaying of traditional male virtues. It could even be argued that his selfmocking tone functions to draw attention to exactly those aspects of his character that it seems to defuse. There is also a difference between the journey he actually made and the journey he wrote. Introducing the section of the narrative dealing with Spitsbergen, Dufferin mentions almost in passing, that it 'has been no child's play to get to see it' (101). He is already performing masculinity by travelling North by sea and there is consequently no need for him to narrate his manliness or to justify the difference of his particular relationship to the North from that of, for instance, Scoresby or other Arctic explorers. He is secure in his privileged position as a well-educated, financially comfortable gentleman. 
Letters from High Latitudes produces a picture of the Nordic North both as a result of what the text does and as a result of what it does not do. The contemporary review in The Times encapsulates the contradictory nature of the work by first outlining that the public expectations of a journey to the far North still include peril and hardship, then indicating that Lord Dufferin's main assets are his taste and breeding:

It is not often that we find as much difficulty in laying down a book of travels as if it were a romance, but this has been the case with this volume. The traveller here was judicious in the choice of a strange and perilous route, - a refreshing contrast to the monotonous fair-weather voyages of ordinary yachtsmen, - happy in his companions, his weather, and his incidents, fortunate in reaching his bourne, and still more fortunate in returning - above all, the right man on the right track; full of fun and frolic, and with a very striking capacity for exhibiting the high talents and taste he inherited. ${ }^{40}$

Even though Dufferin's narrative does not linger on the perilous aspects of the journey, the reviewer still regards the dangers of the North as an important reason for the interest of the book. The harsh, usually masculine-gendered North functions as a kind of cultural intertext or horizon of expectations in the narrative, present as a background even though it is mostly absent from the text itself. The comments directly addressed to Lady Dufferin invoke a competing set of expectations, by directing the narrative to an upper-class, female environment. By distancing himself from the hero-ideal, selecting material corresponding to his understanding of women's tastes and down-playing the dangers of the journey, Dufferin manages to feminise and gentrify both the North and his own approach to it. The Times reviewer is not entirely happy with the resulting stylistic mixture, writing: 'We might perhaps object to a little flippancy and sentimentality here and there, but where there is so much entertainment so gracefully afforded it would be ungracious to dwell on occasional blemishes. ${ }^{41}$ It is quite possible that a contributing factor to the criticism was the common association between a lack of seriousness and femininity. But what was read as flippancy and sentimentality in the cultural climate of the mid-nineteenth-century may today be reinterpreted as a welcome alternative to the rapidly standardised images of the tough, demanding and masculine-gendered North. Letters from High Latitudes helps to show that the coherence of the European view of the North has been considerably overestimated.

\section{Notes}

1. Sherrill Grace, Canada and the Idea of North [2001] (Montreal: McGill-Queen's University Press, 2007), 16; Peter Davidson, The Idea of North (London: Reaktion, 2005), 9.

2. Mrs. Alec Tweedie [Ethel Brilliana Tweedie], Through Finland in Carts [1897] (London: Thomas Nelson \& Sons, 1913), 16-17. I am indebted to Anka Ryall who quoted this passage in her presentation at the symposium Regionens estetiska uttryck och bilden av regionen, Umeå University, 30-31 March 2007, to illustrate how winter is frequently invoked in narratives about the Nordic countries, even when the text describes summer experiences.

3. Review of Lispings from Low Latitudes, or, Extracts from the Journal of the Hon. Impulsia Gushington, Living Age 77.789 (16 May 1863): 310-15 (310). Reprinted from the Examiner.

4. Sir Alfred Lyall, The Life of the Marquis of Dufferin and Ava (London: Thomas Nelson \& Sons, 1905), 27.

5. Lyall, Life of the Marquis of Dufferin, 94-6.

6. James Anderson Scott, 'Icelandic Lore and Scenery', Dublin University Magazine 62 (Jul.-Dec. 1863): 459-60.

7. Sir William Martin Conway, The First Crossing of Spitsbergen (London: J.M. Dent, 1897), 1.

8. Tim Moore, Frost on My Moustache: The Arctic Exploits of a Lord and a Loafer (London: Abacus, 1999). Maria Lindgren Leavenworth uses the term 'second journey' to refer to such travels in the footsteps of famous forebears, Maria Lindgren, 'The Second Journey: Travelling 
in Literary Footsteps', unpublished diss. (Umeå: Dept. of Modern Languages/English, Umeå University, 2000).

9. 'Mr. Colburn's List of New Publications', insert in Memorials of the Great Civil War in England from 1646 to 1652, ed. Henry Cary, 2 vols. (London: Henry Colburn, 1842), 1-16 (9).

10. Andrew Wawn, The Vikings and the Victorians: Inventing the Old North in 19th-Century Britain (Cambridge: D.S. Brewer, 2000), 284.

11. Scott, 'Icelandic Lore and Scenery', 460. The phrase 'dandy order of tourists' is quoted also in Wawn, 284.

12. See Heidi Hansson, 'Bayard Taylor and the Genders of the North', Edda 1 (2006): 18-28.

13. Bayard Taylor, Northern Travel. Summer and Winter Pictures of Sweden, Lapland, and Norway (London: Sampson Low, 1858), 112.

14. Lyall, Life of the Marquis of Dufferin, 95.

15. See Lisa Bloom, Gender on Ice: American Ideologies of Polar Expeditions (Minneapolis: University of Minnesota Press, 1993).

16. In 1854 John Rae of the Hudson's Bay Company received information from Inuit sources that Franklin and his crew had been driven to eating the flesh of their dead comrades before they died, but this information could not be integrated in the view of the Arctic explorer as a hero and led to fierce attacks on Rae by among others Charles Dickens. For further information about John Rae, see Ken McCoogan, Fatal Passage: The Untold Story of John Rae, the Arctic Adventurer Who Discovered the Fate of Franklin (Ontario: HarperFlamingo, 2001). See also Shu-chuan Yan, 'Voyages and Visions: Imag(in)ing the Arctic in the Victorian Periodical, 1850s-1870s', NTU Studies in Languages and Literature 16 (Dec. 2006): 53-82, for a discussion of the images of Arctic exploration in Victorian public journals; especially 55-67 dealing with various public presentations of Franklin's expedition and the subsequent attempts to discover its final fate.

17. Robert G. David, The Arctic in the British Imagination 1818-1914 (Manchester: Manchester University Press, 2000), see particularly Chapter 3, 'A Platform for Heroes: The Role of the Geographical Societies', 63-80.

18. Frederick Temple Blackwood, Lord Dufferin, Letters from High Latitudes: Being Some Account of a Voyage in 1856 in the Schooner Yacht "Foam" to Iceland, Jan Mayen, and Spitzbergen [1857] (London: Dent, 1903), 18. Further references to Dufferin's work are given parenthetically in the text.

19. Lyall, Life of the Marquis of Dufferin, 97.

20. Moore, Frost on My Moustache, 50.

21. Jón Stefánsson, 'Introduction', Frederick Temple Blackwood, Lord Dufferin, Letters from High Latitudes, vii-ix (vii).

22. See Francis Bacon, Essays, or, Counsels, Civil and Moral, ed. and intr. Brian Vickers (Oxford: Oxford University Press, 2002).

23. See Carol J. Singley and Susan Elizabeth Sweeney, eds, Anxious Power: Reading, Writing, and Ambivalence in Narrative by Women (Albany: State University of New York Press, 1993).

24. George C. Brauer, The Education of A Gentleman: Theories of Gentlemanly Education in England, 1660-1775 (New York: Bookman, 1959), 59-61.

25. Steven Shapin, "AA Scholar and a Gentleman": The Problematic Identity of the Scientific Practitioner in Early Modern England', History of Science 29 (1991): 279-327 (312).

26. Brauer, Education of a Gentleman, 66.

27. Morris Berman, “'Hegemony" and the Amateur Tradition in British Science', Journal of Social History 8, no. 2 (1975): 30-50 (35).

28. See Diane P. Freedman, 'Discourse as Power: Renouncing Denial', in Anxious Power: Reading, Writing, and Ambivalence in Narrative by Women, ed. Carol J. Singley and Susan Elizabeth Sweeney (Albany: State University of New York Press, 1993), 363-78.

29. Shirley Foster, Across New Worlds: Nineteenth-Century Women Travellers and their Writings (New York: Harvester Wheatsheaf, 1990), 19.

30. James Duncan and Derek Gregory, 'Introduction', in Writes of Passage: Reading Travel Writing, ed. James Duncan and Derek Gregory (London: Routledge, 1999), 1-13 (3-4).

31. Foster, Across New Worlds, 24.

32. Selina Bunbury, who travelled in the Nordic countries a few years before Dufferin, also notes the divorce laws and suggests that it might even be worth marrying in Sweden just to show how 
easy it is to obtain a divorce. Selina Bunbury, Life in Sweden; with Excursions in Norway and Denmark, 2 vols. (London: Hurst \& Blackett, 1853), vol. 2, 20.

33. Susan Bassnett, 'Travel Writing and Gender', in The Cambridge Companion to Travel Writing, ed. Peter Hulme and Tim Youngs (Cambridge: Cambridge University Press, 2002), 225-41 (241).

34. Duncan and Gregory, 'Introduction', 4.

35. Felix Driver and Luciana Martins, 'Views and Visions of the Tropical World', in Tropical Visions in an Age of Empire, ed. Felix Driver and Luciana Martins (Chicago, IL: University of Chicago Press, 2005), 3-20 (8).

36. See Louis-Edmond Hamelin, The Canadian North and its Conceptual Referents (Ottawa: Department of the Secretary of State of Canada, 1988).

37. Dufferin's view of the Vikings as the forefathers of British aristocrats was apparently influenced by the lengthy introduction to Samuel Laing's 1844 translation of Snorri Sturluson's thirteenthcentury saga chronicle of the kings of Norway Heimskringla, or, Chronicle of the Kings of Norway. See Andrew Wawn, 'Samuel Laing, Heimskringla, and the Victorian "Berserker School", in Anglo-Scandinavian Cross-Currents, ed. Inga-Stina Ewbank, Olav Lausund and Bjørn Tysdahl (Norwich: Norvik, 1999), 29-59 (59, note 81).

38. Brauer, Education of a Gentleman, 102.

39. Anne M. Windholz, 'An Emigrant and a Gentleman: Imperial Masculinity, British Magazines, and the Colony that Got Away', Victorian Studies 42, no. 4 (1999): 631-58 (633).

40. 'Letters from High Latitudes', The Times, 20 October 1857, 9, col. B.

41. 'Letters from High Latitudes', 9. 